\title{
Breast Ductal Adenoma
}

National Cancer Institute

\section{Source}

National Cancer Institute. Breast Ductal Adenoma. NCI Thesaurus. Code C40384.

A benign, well circumscribed neoplasm that is located within the lumen of a duct in the breast parenchyma. It is characterized by the presence of glandular structures at the periphery and fibrous tissue at the center of the tumor. 